\title{
ORGANIZATIONAL JUSTICE AND ORGANIZATIONAL COMMITEMENT'S EFFECT ON JOB SATISFACTION: A RESEARCH ON DOCTORS
}

\author{
DOI: 10.17261/Pressacademia.2018.923 \\ PAP- V.7-2018(76)-p.393-402
}

\section{Yesim Korkut ${ }^{1}$, Yurdagul Meral ${ }^{2}$}

${ }^{1}$ Istanbul Medipol University, Unkapanı Kampüsü, Beykoz, Istanbul, Turkey. ykara@medipol.edu.tr, ORCID: 0000-0001-8170-383X

${ }^{2}$ Istanbul Medipol University, Kavacık Kampüsü, Beykoz, Istanbul, Turkey. ymeral@medipol.edu.tr, ORCID: 0000-0001-9244-1994

\section{To cite this document}

Korkut, Y., Meral, Y. (2018). Organizational justice and organizational commitement's effect on job satisfaction: a research on doctors. PressAcademia Procedia (PAP), V.7, p.393-402.

Permemant link to this document: $h$ ttp://doi.org/10.17261/Pressacademia.2018.923

Copyright: Published by PressAcademia and limited licenced re-use rights only.

\begin{abstract}
Purpose- It is aimed to investigate the mediating effect of emotional commitment on the relationship between operational justice and job satisfaction on physicians. . At the same time, the relationship between organizational justice and organisational commitment, between organisational justice and job satisfaction and between organisation commitment and job satisfaction are also investigted. According to the demographic characteristics of physicians, perceptions of organizational justice, organizational commitment and job satisfaction were measured.

Methodology- Our sample consisted of 489 physicians and the data were obtained by questionnaire method. Using the SPSS 22 statistical program, frequency and percentage breakdowns for participants' responses, factor analysis and normality distributions of data were made. After the reliability and validity analyzes of the scales were performed, Spearman correlation and regression analyzes were conducted to test the hypotheses.

Findings- As a result of the research, it was found that the relationship between transactional justice and job satisfaction is mediated by emotional commitment, and the relationships between organizational justice and organizational commitment, organizational justice and job satisfaction and organizational commitment and job satisfaction are significant and positive.

Conclusion- At the same time, when we look at the severity of relations among our variables, the strongest relationship is reached between organizational justice and job satisfaction.
\end{abstract}

Keywords: Organizational justice, organizational commitment, job satisfaction, doctors.

JEL Codes: M1, M10, J28

ÖRGÜTSEL ADALETIN, ÖRGÜTSEL BAĞLILIK VE IŞ DOYUMU ÜZERINE ETKILERI: HEKIMLER ÜZERINDE BIR ARAŞTIRMA

\section{ÖZET}

Amaç- Calışmamızda hekimler üzerinde, ișlemsel adalet ve is doyumu ilișkisinde duygusal bağııı̆ı̆n aracılık rolü araștııılmıştır. Aynı zamanda örgütsel adalet ile örgütsel bağlılık arasındaki ilişki, örgütsel adalet ile iş doyumu arasındaki ilişki ve örgütsel bağlılık ile iş doyumu arasındaki iliş̧inin araştııııması da amaçlanmıştır.

Yöntem- Örneklemimizi 489 hekim oluşturmakta olup, veriler anket yöntemi ile elde edilmiştir. SPSS 22 istatistik programı kullanılarak, katııımcıların cevaplarına yönelik frekans ve yüzde dökümleri, verilerin faktör analizi ve normallik dağıımları yapılmıştır. Ölçeklerin güvenilirlik ve geçerlilik analizi yapıldıktan sonra, hipotezlerin testine yönelik Spearman Korelasyon ve Regresyon analizleri yapılmıştır. Bulgular- Araştırma sonucunda, işlemsel adalet ile iş doyumu arasındaki ilişki de duygusal bağlıığın aracılık rolünün olduğu, örgütsel adalet ve örgütsel bağ|lık, örgütsel adalet ve iş doyumu ve örgütsel bağlılık ve iş doyumu arasındaki ilişkilerin anlamlı ve pozitif yönlü olduğu sonuçları elde edilmiştir.

Sonuç- Aynı zamanda değişkenlerimiz arasındaki ilişkilerin şiddetine bakıldığında en güçlü ilişki, örgütsel adalet ve iş doyumu arasında olduğu sonucuna ulaşılmıştır.

Anahtar Kelimeler: Örgütsel adalet, örgütsel bağ|lıık, iş doyumu. JEL Kodları: M1, M10, J28 


\section{GíRiş}

İnsan kaynağı kamu ve özel sektörde yer alan tüm örgütlerin başarılarında temel faktördür. Ancak yeterli bilgi ve donanıma sahip olan örgütler, varoluş amacı olan hizmet sunumunda üstünlük elde edebilmektedirler. Bu üstünlügün devam edebilmesi için; nitelikli ve iyi yetişmiş olan çalışanlarda adaletli bir ortam sunarak çalışanların iş doyumunu ve örgüte olan bağlılığını sağlayabilmek esastır. Adaletin olmadığı bir çalışma ortamında, örgüte bağılıık ve iş doyumundan da söz edilemez.

Çalışanlar örgütteki diğer çalışanlarla kendilerini karşılaştııılar ve haksız bir durumun varlığını hissettiklerinde örgütten fiziksel ve duygusal olarak uzaklaşırlar. Bunun neticesinde bireyin motivasyonu düşer ve örgütsel bağılıık düzeyi de olumsuz yönde etkilenir. Örgütler amaçlarına ulaşabilmek için, insan unsuruna gereken önemi vererek bireyin iş tatmininin artması yönünde yatıım yapmalıdırlar.

Çalışmamızın amacı, kamu ya da özel kurumda çalışan hekimlerin işlemsel adalet ile iş doyumu ilişkisinde duygusal bağlıı̆̆ın aracılık rolünü, örgütsel adalet ile örgütsel bağılıık arasında, örgütsel adalet ile iş doyumu arasında, örgütsel bağlıık ile iş doyumu arasındaki ilişkinin yönü ve gücünü belirlemektir.

Bu kapsamda yazarın yayınlanmamış yüksek lisans tezi baz alınarak yapılan bu çalışmada aşağıdaki soruların cevapları araştırılmaktadır.

Hekimlerin;

1) Hekimlerin duygusal bağlılı̆ının, işlemsel adalet algıları ile iş doyumu arasında aracılık etkisi var mıdır?

2) Hekimlerin adalet algısı ile örgütsel bağılıı̆ı arasında olumlu ilişki var mıdır?

3) Hekimlerin adalet algısı ile iş doyumu arasında olumlu ilişki var mıdır?

4) Hekimlerin örgütsel bağııı̆̆ı ile iş doyumu arasında olumlu ilişki var mıdır?

\section{1. ÖRGÜTSEL ADALET}

Adalet kavram olarak, kurum içi karar ve politikaların herkes için aynı düzeyde uygulanması olarak ifade edilmektedir. Örgütsel adalet kavramı 1980'lerden sonra ilk defa Greenberg (1987) tarafından kullanılması neticesinde ortaya çıkmıştır. Örgütsel adalet, bireyin yer aldığı örgütteki uygulamalar ile ilgili olarak algılanan adalettir (Greenberg,1996: 24).

Organizasyondaki idarenin herkese eşit kurallar uygulayıp uygulamadığı, ücret adilliği, izin ve diğer sosyal haklardan yararlanmak gibi konularda çalışanlar kendisini diğer çalışanlarla karşılaştırmaktadır. Ancak, çalışanlarda oluşan adalet algısının odağını sadece çıktılar oluşturmamaktadır. Örgüt tarafından çalışanlara uygulanan kurallar ve bunun neticesinde oluşan bireyler arasındaki etkileşime de odaklanılmaktadır (Özdevecioğlu, 2004: 185).

Organizasyon içindeki işleyişin devamlılı̆ı için çalışanın adalet algısı oldukça önem arz ettiğinden, örgütsel adalet günümüzde yönetim bilimi araştırmacıları tarafından üzerinde durulan bir olgu haline gelmektedir.

\section{1. Örgütsel Adalet Boyutları}

Örgütsel adalet üç boyuttan oluşmaktadır.

\subsubsection{Dağıtımsal Adalet}

Dağııımsal adalet, Adams'ın Eşitlik Teorisine dayanmaktadır. Adams'ın Eşitlik Teorisi, bireyin kendi kazanımlarını diğer bireylerin kazanımlarıyla kıyaslayarak aralarında eşitliğin olup olmadığını araştırmasıdır (Yazıcıoğlu, 2009: 4).

Dağıtımsal adalet algısına ilişkin gösterge; çalışanın bilgi, yetenek ve becerisini örgütün amaçlarına kanalize etmesi ile doğru orantılı olacak şekilde, yöneticilerin geliştirecekleri eşdeğer karşılığın eşit işe eşit ücret, çalışma şartlarında iyileştirme, ödüllerin adil dağıımı gibi unsurların örtüşmesidir (Yeniçeri vd.,2009: 85).

Örgütte çalışan bireyler maaş, terfi, prim gibi kazançlarını başka bireylerin kazançları ile mukayese ederek sonuçların adaletli veya adaletsiz olup olmadığını algılamaktadır. Bunun neticesinde birey, kendi kazançlarında objektif hareket edilmediğini veya davranılmadığını düşünerek etki altında kalması durumunda negatif yönde etkilenebilir. Dağıtımsal adalet kazancında temel düşünce, çalışanların, dağıtılan kaynaklardan (prim, maaș, terfi, ve ceza gibi) adaletli bir șekilde pay aldığını düşünmesidir

Dağıtımsal adalet, örgütte çalışane hak ettiğini vermeyi gerektirdiğinden sonuçların dağııımında eşitliğe, hakkaniyete ve ihtiyaca dikkat edilmelidir. Bu çerçevede sonuçlar dağıııldı̆ında çalışan memnuniyetinin artması ve örgüte bağlılı̆̆ı da sağlanabilecektir.

\subsection{2. İşlemsel Adalet}

İşlemsel (süreç) adalet elde edilen çıktıların nasıl elde edildiği ve bu aşamada hangi süreçlerin kullanıldığı ile ilgilidir (Aslantürk ve Şahan, 2012: 138). Işslemsel adalet algısının temeli, bireylerin elde ettikleri kazanımlar ve alınan kararların plan aşaması ve alınan kararların faaliyete geçirilme aşamalarının adaletli olması ile şekillenmektedir (Jeon, 2009: 20).

İşlemsel adalet, kararların alınmasında ve kuralların uygulanmasında kullanılan süreçlerin adaletli olması, ödemelerin eksiksiz yapılması, sonuçlar hakkında çalışanlara bilgi verme gibi işlemlerin tüm örgüt çalışanlarına adil olarak paylaştırılmasıdır. İşlemsel adalet, dağııım adaleti ile birlikte uygulanmalıdır (Meral ve Yaşlıoğlu, 2017: 954). 
Bireyler örgütte alınan kararlarda ve uygulamalarda kendilerinin etkisinin olduğunu algıladıklarında yapılan işlemleri adil olarak görmekte ve bu süreçte elde edilen çıktı, arzulanmayan bir sonuç olsa bile, sonucu olumlu bir şekilde değerlendirilmektedir (Özmen, Arbak ve Özer, 2007: 22).

Örgüt içindeki yönetici, kararlardan etkilenen çalışanların bu kararların alınmasındaki süreçlerde onayını ve gerçekleşen sürecin tarafsızlığını sağlayabiliyorsa, işlemsel adaleti uygulamayı başarmaktadır (İşcan ve Naktiyok, 2004: 187).

Levental'a göre, örgüt içinde adalet algılamalarını doğrudan etkileyecek 6 temel kural bulunmaktadır. Bu kurallar şunlardır (Leventhal, 1980: 42-48):

(a) Tutarlılık kuralı: Dağıtım kararlarıyla ilgili alınacak kararların birbirleriyle

tutarlı olmasıdır

(b) Önyargılı olmamak kuralı: Dağıtımda veya işlemde örgüt çalışanlarına karşı önyargılı olmamaktır.

(c) Doğruluk kuralı: Bilgilerin doğruluğu ile ilgili kuraldır.

(d) Düzeltebilme kuralı: Alınan bazı kararlara çalışanların itiraz edebilmeleri veya o kararları düzelttirebilme haklarının olması ile ilgilidir.

(e) Temsilcilik kuralları: Çalışanları etkileyecek kararların alınmasında onlardan temsilciler seçilmesi ve sorulmasıyla ilgilidir.

(f) Etik kural: Alınacak kararların, özellikle dağıtım ve işlemle ilgili, çalışanların etik değerleri ile aynı yönde olması gerektiğine yönelik kuraldır.

Bireyler içinde bulunduğu örgütte işlemsel adaletsizlikle karşılaşırlarsa, adaletsizliğin neden olduğu kaynaktan çok örgütün tamamına karşı olumsuz bir tutum içinde bulunmaktadırlar (Özdevecioğlu, 2003: 79).

İşlemsel adaletin varlığı, örgütün global olduğunu ortaya koymakta olup, güçlü performans, örgütsel bağlılık, örgütsel vatandaşlık ve örgüte devam belirleyicisi olarak kabul edilmektedir (Witt, Kocmar ve Andrews, 2001).

\subsubsection{Etkilessimsel Adalet}

Etkileşimsel adalet, örgüt içi adaletin sosyal yanına dikkat çekmekte olup, kararların alınmasından sonra, alınan kararların çalışanlara söylenme biçimi ile ilgilenmektedir. Organizasyonel işlerin insancıl yönünü ele alan etkileşimsel adalet, adaleti dağıtan ve adalete ya da adaletsizliğe maruz kalan taraflar arasındaki diyaloglara dikkat etmektedir (Özmen, Arbak ve Özer, 2007: 22).

Greenberg, 1993 yılında yayınlamış olduğu çalışmasıyla adaleti hissetme olgusuna yeni boyutlar kazandırmış olup, etkileşimsel adaleti "kişilerarası adalet" ve "bilgisel adalet" olarak ikiye ayırmıştır. Birinci boyut olan kişilerarası adalet, karar uygulayıcılarının karardan etkilenen kişilere nazik ve saygın davranıp davranmamasıyla ilgilidir. İkinci boyut olan bilgisel adalet ise, kararın dayanağı olan temel düşüncenin, kararı etkileyen kişilere yeterli derecede açıklayıp açıklanmamasıyla ilgilidir (Cihangiroğlu, 2011: 10).

Kişilerarası adalet, yöneticilerin çalışanlara karşı saygı ve nezaket kuralları çerçevesinde ve alınan kararlarda çalışanların haklarına uygun davranmalarını gerektirmektedir. Bilgisel adalet boyutundaysa, çalışanlara karşı yapılan açıklamalar ve sosyal değerlendirmeler yer almaktadır. Eğer çalışan herhangi bir şeyden mahrum kalıyorsa bu durumun çalışana açıklanması gerekmektedir. Bu boyutta yöneticilerin örgütsel işlemler, çalışanların özlük ve sosyal hakları konusunda astlarını bilgilendirmeleri, çalışanların bilgi edinme hakları ve çıkarlarının korunması konusunda da saygı duymaları gerekmektedir.

Örgüt içindeki iletişim sürecinde çalışanların adalet algılarını saygı dürüstlük ve nezaket gibi unsurlar etkilemektedir. Çalışanın örgütteki etkileşimsel adaleti düşük olarak algılaması da buna neden olan kişilere ya da birimlere karşı olumsuz bir tutum içine girmesine neden olmaktadır.

\section{2. ÖRGÜTSEL BAĞLILIK}

Organizasyonların başarıları için önemli bir etken olan örgütsel bağılık literatürde oldukça fazla çalışılan bir araştırma konusudur. "Morrow" literatürde örgütsel bağlılıkla ilgili yirmi beşin üzerinde değişik tanımın bulunduğunu belirtmektedir" (Yüceler, 2009: 447). Yapılan bazı tanımlamalar şu şekildedir (Bakan, 2011: 7-10)

- Grusky'e göre (1966), örgütsel bağlılık “bireyin örgüte bağının gücü” dür.

- Leong'a göre, örgütsel bağlılık "bireyin bir örgüt ile girdiği kimlik birliği ve bağlılığının birleşik gücü" dür.

- Morris, Lydka ve O’Creevy, örgütsel bağlılığı "bireyin bütünleşme ve gönüllülük eğilimi” olarak açıklamaktadır.

- McDonald ve Makin'e göre, örgütsel bağlılıkta kişi ile örgüt arasında gerçekleştirilen psikloljik sözleşmedir.

- Meyer ve Allen'e göre, örgütsel bağlılık, "Çalışanın çalıştığı işletmede işine devam etme isteğinde olması, işyerine düzenli olarak gelmesi, işletmenin varlıklarını koruması ve işletmenin amaçları ile bütünleşmesidir"

- Rusbult ve Farrel'a göre, "Kişinin tatmin edici olmasa bile bir işe saplanıp kalması ve kendini işine psikolojik olarak bağlanmış hissetmesidir" (Gül, 2002: 38).

- Rietzer ve Trice'e göre örgütsel bağlılık ise "örgütün kişiye göre anlamlılık düzeyine dayanan psikolojik bir olgudur" (Yüceler, 2009:449).

- Weiner'a göre "örgütsel çıkarları karşılayacak şekilde hareket etmek için içselleştirilmiş normatif baskıların bir toplamıdır” (Gül, 2002: 38). 
- Becker’a (1960) göre ise, “işletmeye bağlılık, kişinin örgütte çalıştığı süre içinde sarf ettiği emek, zaman, çaba ve edindiği statü ve para gibi değerleri örgütten ayrıldığı zaman kaybedeceği ve bütün yaptıklarının boşa gideceği korkusu sonucu oluşan bağlılıktır" (Gül, 2002: 39).

Örgütsel bağlıığın en çok kabul gören tanımlaması Porter, Mowday ve Steers'a ait olandır ve bu tanıma göre de örgüte bağılığın öğeleri aşağıda verilmektedir (Gül, 2002: 39) :

a. Örgütün amaç ve değerlerini kabullenme ve bunlara güçlü bir inanç duyma,

b. Örgüt yararına beklenenden daha fazla çaba harcama,

c. Örgüt üyeliğinin devamı için güçlü bir istek duyma.

Örgütler için, örgütsel bağlılık konusu son yıllarda ilk sıralardaki amaçlar arasında yerini almaktadır. Bunun nedeni de örgütlerin insan odaklı olması ve örgütte aidiyet duygusuyla çalışanların aynı zamanda yüksek seviyede üretken olmaları, sorumluluk bilinciyle hareket etmelerinin yanı sıra işi bırakma, devamsızlık gibi örgüte zarar verici durumlarda söz konusu olmamaktadır. Aynı zamanda örgüte bağlılığı yüksek olan çalışan örgütün maliyetlerini de düşünmektedir.

Meyer ve Allen'in (1991) örgütsel bağlılık modeli, son yıllarda literatürde en çok kullanılan ve araştırmacılar tarafından kabulü en fazla olan yaklaşımdır. Meyer ve Allen (1984) çalışmalarında örgütsel bağlılı̆ı duygusal ve devam bağılığı olarak iki gruba ayırmışlardır. Daha sonra Weiner ve Vardi'nin (1980) önerisi ile üçüncü bir boyut olarak normatif ya da ahlaki bağlılık eklenmiş ve üç boyutlu örgütsel bağlılık modelini oluşturmuşlardır (Allen ve Meyer, 1990: 2).

\section{a) Duygusal Bağlılık}

$\mathrm{Bu}$ bağlılık türü, çalışanların içinde yer aldığı örgüte karşı pozitif duygularla psikolojik olarak bağlanması olarak tanımlanmaktadır (Chang,1999: 67). Çalışanların örgüte karşı duygusal bağlılığı, örgütün amaçlarını, değerlerini ve hedeflerini benimsemesi ile doğru orantılı bir bağlılık türüdür. Çalışanın örgütün değerlerini benimsemesi, kendisini içinde bulunduğu örgütün bir parçası olarak görmesi ve bunun devamlıığını istemesi duygusal bağlıı̆ğından kaynaklanmaktadır. Örgüte karşı en güçlü sağlanabilecek bağııık türü olan duygusal bağlılık, örgütlerin de çalışanlarında daima isteyeceği bir bağlılık türüdür. Çünkü bu şekilde örgütüne bağlı olan çalışan her zaman gerekenden fazla çaba sarf ettiği gibi işine karşı da olumlu bir tutum sergilemektedir (Bayram, 2005: 132).

\section{b) Devamlılık Bağlılığı}

Literatürde rasyonel bağııık olarak da bilinen devamlılık bağlılığı, çalışanların örgütten ayrılmalarının beraberinde gelecek olan maliyetlerin farkında olmaları anlamına gelmektedir. Bu maliyetler, başka bir örgüte uyum sağlayamamak, içinde olduğu örgütten tazminatlarını alamamak, işin gerektirdiği niteliklere sahip olamamak, işsiz kalmak gibi durumlarla oluşabilecek maliyetlerdir. Yani bu bağlılık türü çalışanların örgütte kalma ihtiyaçlarından doğmaktadır (Doğan ve Kılıç, 2005: 45).

Devam bağlılığı yüksek olan çalışanlar mali kazanımlarını kaybetmemek için örgütte kalmayı bir zorunluluk olarak görmesine ilave olarak başka bir iş alternatiflerinin de olmaması veya az olması nedeniyle örgütte devamlılıklarını sürdürmektedirler.

\section{c) Normatif Bağlılık}

Meyer ve Allen (1990), normatif bağlılığı çalışanların örgütteki devamlılıklarının temelinde çalışanın örgütte kalma zorunluluğu duygusunun olduğunu ifade etmişlerdir. Bu bağlılık türü, çalışanların örgütteki devamı ile ilgili olarak zorunluluk duymalarından kaynaklanmaktadır. Bu nedenle de normatif bağlılığı yüksek olan kişiler örgütte çalışıyor olmalarını, bu durumun hem doğruluğuna inandıkları için hem de ahlaki duygulara dayandığından ve çıkara bağlı olmadan devam ettirmektedirler (Meyer ve Allen, 1997).

Normatif bağlılığı yüksek kişiler örgütteki varlığını sorumluluk bilinci ile sürdürmektedirler. Çalışanların örgüte duyduğu bağlıık, çalışanın kendi değerlerine uygun davrandığına inanmasından kaynaklanmaktadır. Yani çalışanın etik değerlerinin katkısı bu bağlılı̆ın oluşumunda oldukça önemli bir faktördür.

\section{3. iş DOYUMU}

Hem örgütsel davranışın, hem de insan kaynakları disiplinlerinin konuları arasında önemli bir yer tutan iş doyumu (Pekdemir, 2006: 11), çalışanın kurumda çalıştığı süre zarfında elde ettiği tecrübeler sonucu pozitif duyguları, işine ve çevresine karşı pozitif davranış ve algılamaları olarak tanımlanmaktadır (Pool, 1997: 11).

İş doyumu, çalışanların örgüte girişleri sırasında oluşan beklentileri neticesinde, yaptıkları işten elde ettiklerinin kendisinde oluşturduğu olumlu duygular olarak da ifade edilebilir (Adams, 1965: 268).

Bu tanımdan yola çıkarak iki değişkenden söz etmek mümkün görülmektedir. Bunlar; yapılan iş ve elde edilenlerdir. Bu değişkenler arasında da bir oran mevcut olup, çalışanların memnuniyeti de bu iki değişken ile yaptıkları karşılaştırmalar neticesinde belirlenmektedir.

Araştırmacıların iş doyumu konusuna ağırlık vermelerinin temel nedeni olarak, işe karşı çalışanlarda oluşan pozitif ve negatif tutumların örgütsel davranış üzerindeki güçlü etkisi olduğu söylenebilmektedir. İş doyumu yüksek olan çalışanın örgüte faydası daha fazla olmaktadır. İş doyumu düşükse, çalışanlarda bahanelerle işe gelmeme, işe karşı ilgisizlik, örgütün kural ve değerlerini önemsememe, sürekli şikâyetleri dile getirme gibi durumlar söz konusu olabilmektedir. Bu durumlarda iş doyumunun örgüt için neden bu kadar önemli olduğunun anlaşıımasını sağlamaktadır. 
Bireyler günlük zamanlarının büyük kısmını çalışarak geçirdikleri için, çalışanların iş doyumu sağlaması fizyolojik ve psikolojik sağlığı açısından oldukça önem arz etmektedir. İş doyumsuzluğu yukarıda saydığımız durumların yaşanmasına neden olurken, iş doyumu yüksek olan çalışanların fiziksel ve ruhsal açıdan iyi oldukları ve örgüte yaptıkları katkının fazla olduğu gözlenmektedir.

Kimi çalışanı ücret motive ederken, kimini terfi olanakları motive edebilmektedir. Bu noktada çalışanların iş doyumlarını etkileyen faktörlerin belirlenmesi önem arz etmektedir. İş doyumunu, kişilik, yaş, cinsiyet, medeni durum, eğitim düzeyi, sosyo kültürel çevre gibi bireysel faktörler ve işin kendisi, ücret, yönetim, çalışma koşulları, çalışma arkadaşları, terfi olanakları gibi örgütsel faktörler etkilemektedir.

\section{ARAŞTIRMA YÖNTEMI VE BULGULARI}

\subsection{ARAŞTIRMA YÖNTEMI}

Araştırmada literatür taraması sonucu çeşitli kaynaklardan yararlanılarak ölçekte kullanılacak sorular tespit edilerek, soru formu oluşturulmuştur. Veri toplama aracı olarak anket dört bölümlü bir anket formu uygulanmıştır. Anket formunun ilk bölümünde katılımcı hekimlerin demografik özelliklerini belirlemeye yönelik, cinsiyet, yaş, medeni durum, unvan, çalışılan kurum, toplam mesleki deneyim süresi, değerlendirilen kurumdaki deneyim süresine ilişkin ifadeler yer almaktadır. İkinci bölümde işlemsel adalet, üçüncü bölümde duygusal bağlılık, dördüncü bölümde de iş doyumu algılarına yönelik ifadeler bulunmaktadır.

Soru formunda kullanılan ölçeklere ilişkin ifadelerin daha anlaşılır olmasını sağlamak için, anket formu hazırlık sürecinde, gözden geçirilen ölçek soruları önce İngilizce'den Türkçe'ye çevrilmiştir. Türkçe'ye çevrilen ölçekler daha sonra tekrar İngilizce'ye çevrilerek, iki İngilizce metin karşılaştırılarak anket formu hazırlanmıştır.

İşlemsel adalet algısını ölçebilmek için Niehoff ve Moorman (1993) tarafından geliştirilen örgütsel adalet ölçeğinin, işlemse adalet boyutunu ölçen 6 ifade kullanılmıştır. Duygusal bağlılık algısını ölçmek için Allen ve Meyer (1990) tarafından geliştirilen örgütsel bağlılık ölçeğinin, duygusal bağlıık boyutunu ölçen 6 ifade kullanılmıştır. İşlemsel adalet ve duygusal bağlılık ölçekleri beşli likert tipi olarak formda yer almış olup, "1= Kesinlikle Katılmıyorum", "2= Katılmıyorum", “3= Kararsızım”, "4= Katılıyorum” ve "5= Kesinlikle Katılıyorum" cevaplarını içermektedir.

İş doyum algısını ölçmek için Weiss, Davis England ve Lofquist (1967) tarafından geliştirilen Minnessota Doyum Ölçeği (Minnessota Satisfaction Questionnaire)'nden yararlanılmıştır. Ölçek 20 ifadeden oluşmakta olup, 1.2.3.4.7.8.9.10.11.15.16. ve 20. ifadeler içsel doyumu, 5.6.12.13.14.17.18. ve 19. ifadeler dışsal doyumu ölçmektedir. Ölçek beşli likert tipi olarak formda yer almakta olup, "1= Hiç Memnun Değilim, "2= Memnun Değilim”, "3= Kararsızım”, "4= Memnunum” ve "5= Çok Memnunum” cevaplarını içermektedir.

Araştırmanın Amacı ve Önemi: Literatür taraması doğrultusunda, araştırmamızın temel amacı, çalışanın işlemsel adalet ve iş doyumu ilişkisinde duygusal bağlılığın aracılık rolünü belirlemektir. Ayrıca örgütsel adalet ile örgütsel bağlılık, örgütsel adalet ile iş doyumu ve örgütsel bağlılık ile iş doyumu arasındaki ilişkinin yönü ve şiddeti ölçülmüştür.

Çalışmamızın örneklemini oluşuran hekimlerin demografik özelliklerine göre, adalete, örgütsel bağlılığa ve iş doyumuna ilişkin algılarının ölçülmesi de ayrıca amaçlanmıştır.

Çalışmamızda kamu ve özel hastanelerde çalışan hekimlerin algılarının yanı sıra kendi muayenehanesinde çalışan hekimlerinde en son çalıştıkları kamu veya özel sektörde bulunan hastanedeki örgütsel adalet, örgütsel bağlılık ve iş doyumu algılarını ölçmeye yönelik bir çalışma yürütülmüştür. Bu anlamda da yine literatürde yer almayan bir çalışma olduğu ve literatüre katkı sağlayacağı düşünülmektedir.

\section{Araştırma Hipotezleri}

$\mathrm{H}_{1}$ : İşlemsel adalet algıSı, duygusal bağlılık aracı değişkeni ile çalışanların (hekimlerin) iş doyumunu olumlu etkilemektedir.

$\mathrm{H}_{2:}$ Örgütsel adalet algısı ile hekimin örgütsel bağlılığı arasında olumlu ilişki vardır.

$\mathrm{H}_{3}$ : Örgütsel adalet algısı ile hekimin iş doyumu arasında olumlu ilişki vardır.

$\mathrm{H}_{4}$ : Örgütsel bağııık ile hekimin iş doyumunu arasında olumlu ilişki vardır.

Ana Kütle ve Örneklem: Bu araştırma kapsam itibari ile Türkiye'de kamu ve özel hastanelerde veya son çalıştıkları kuruma yönelik algılarının ölçülmesi amaçlanan, kendi özel muayenehanesinde çalışan hekimler üzerinde yürütülmüştür. Bu araştırmanın evrenini İstanbul Medipol Üniversitesi Geleneksel ve Tamamlayıcı Tıp araştırma Merkezinin, 6 aylık süre zarfında eğitimlerine katılan 700 hekim oluşturmaktadır.

700 adet anket formu 16 Eylül ve 2 Aralık 2017 tarihleri arasında, mail ve doğrudan dağıtım şeklinde hekimlere ulaştırılmıştır. Mail ile gönderilen 150 formun 45 tanesi, doldurularak tekrardan mail ile tarafımıza ulaştırılmıştır. 550 adet de elden dağıtılmış olan anket formlarının 444 adet anket formu doldurularak teslim edilmiştir. Toplam 489 adet anket veri girişi yapılmıştır.

Verilerin Analizinde Kullanılan Yöntemler: Veriler toplandıktan sonra elde edilen verilerin analizinde SPSS 22 istatistik programı kullanılmıştır. Araştırmaya katılan katılımcılarla ilgili genel bilgilerin frekans ve yüzde dökümleri elde edilmiştir. Hipotezlerin test edilebilmesi için öncelikle araştırmaya katılan hekimler ile ilgili genel bilgiler demografik özellikler başlığı altında incelenmiştir. Verilerin faktör analizi ve normallik dağılımları yapılmıştır. Araştırmada hekimlerin örgütsel adalet algısının, örgütsel bağlılık ve iş doyumu üzerine etkilerini ölçmek amacıyla, ölçeklerin güvenilirlik ve geçerlilik analizi yapılmış ve daha sonra hipotezlerin testine yönelik olarak spearman korelasyon analizi, regresyon analizi, mann whitney u analizi ve kruskal wallis analizi yapılmıştır. 
Araştırma Değişkenleri Ölçekleri İfadeleri Güvenilirlik Analizleri (Cronbach Alfa Katsayı Değerleri): Tüm değişkenlerin güvenilirliklerini ölçmek amacıyla Cronbach Alfa Katsayısı (Cronbach Alpha Coeficient- $\alpha$ ) incelenmiştir. Ankette yer alan soruların birbiri ile olan tutarlıı̆ını ve kullanılan ölçeğin ilgili kavramı ne derece ölçtüğü bu değer aracılığıyla ortaya konmaktadır.

Cronbach Alfa Katsayısına bağlı olarak ölçeğin güvenilirlik sonuçları aşağıdaki gibi yorumlanmaktadır (Kalaycı, 2009: 24) ;

- $\quad 0.00 \leq \alpha<0.40$ ise ölçek güvenilir değil,

- $\quad 0.40 \leq \alpha<0.60$ ise ölçeğin güvenilirliği düşük,

- $\quad 0.60 \leq \alpha<0.80$ ise ölçek oldukça güvenilir,

- $\quad 0.80 \leq \alpha<1.00$ ise ölçek yüksek derecede güvenilirdir.

Çalışmamızda yer alan değişkenlerin ölçekleri Tablo.1'de gösterilmektedir. Değişkenlere ve değişkenlerin alt boyutlarına ait güvenilirlik kat sayısı 0,958 ile 0,804 arasında değişmektedir.

Tablo 1: Güvenilirlik Analizi Sonuçları Tablosu

\begin{tabular}{|l|l|l|}
\hline & Kullanılan Soru Sayısı & Güvenilirlik Katsayısı \\
\hline Ölşek & 6 & 0,898 \\
\hline Duygusal Bağıııı & 6 & 0,804 \\
\hline İş Doyumu & 20 & 0,958 \\
\hline İçsel Doyum & 12 & 0,937 \\
\hline Dışsal Doyum & 8 & 0,913 \\
\hline
\end{tabular}

İşlemsel adaletin \%89, duygusal bağılı̆ı̆ın \%80, iş doyumunun \% 95 üzerinde güvenilir olduğu sonucuna ulaşılmıştır. Dolayısıyla, araştırma verilerine ait aşağıdaki tablolarda verilen sonuçlar, araştırmada kullanılan ölçeğin içsel tutarlıı̆a sahip olduğunu ortaya koymaktadır.

\section{Araştırma Değişkenleri Ölçekleri Yapı Geçerliliği (Faktör Analizi):}

Faktör analizi, aynı yapıyı ölçen çok sayıda değiş̧kenden, az sayıda ve tanımlanabilir özellikte anlamlı değişkenler elde etmeye yönelik çok değişkenli bir istatistiki analizdir (Büyüköztürk, 2002: 485).

Faktör analizinin amacı, araştırma değişkenleri arasındaki ilişkiyi daha yakından inceleyip, sistemin işleyiş özelliklerini açıklamaktır.

Faktör analizinde örneklem yeterliliğini test etmek amacılla Kaiser-Meyer-Olkin (KMO-örnekleme yeterliliği istatistiği) ve tüm ölçeklere değişken bazında yapılan faktör analizi sonuçları paylaşıımıştır.

Toplanan verilerin, analize uygun olup olmadığını belirlemek için KMO değerinin 0,50’ den büyük olması gerekmektedir.

Tablo 2: KMO Değerler Tablosu (Sipahi ve diğerleri, 2008: 54)

\begin{tabular}{|l|l|}
\hline KMO DEĞERi & YORUM \\
\hline 0,9 & Mükemmel \\
\hline 0,8 & Çok iyi \\
\hline 0,7 & İyi \\
\hline 0,6 & Orta \\
\hline 0,5 & Zayıf \\
\hline 0,50 'nin altı & Kabul Edilemez \\
\hline
\end{tabular}

Çalışmamızda yer alan üç değişken için yapılan faktör analizi sonuçları aşağıda yer almaktadır.

\section{Tablo 3: Değişkenlerin Faktör Analizi}

\begin{tabular}{|l|l|}
\hline İşlemsel Adalet Kaiser-Meyer-Olkin Ölçek Geçerliliği & 0,956 \\
\hline Duygusal Bağlılık Kaiser-Meyer-Olkin Ölçek Geçerliliği & 0,888 \\
\hline İ̧̧ Doyumu Kaiser-Meyer-Olkin Ölçek Geçerliliği & 0,956 \\
\hline
\end{tabular}

Yapılan faktör analizi sonucuna göre \%66 oranında Toplam Açıklanan Varyans (Total Variance Explains) elde edilmiş olup, faktör analizi için temel bileşenler analizi ile Varimax (dik) döndürme yöntemi kullanılmıştır. Verilerin örgütsel adalet ve iş doyumu değişkenleri için KMO katsayısı mükemmel, örgütsel bağlıık değişkeni için elde edilen değerinde çok iyi olarak tanımlanabileceği sonucuna ulaşılmaktadır. Bulunan KMO katsayıları verilerin analize uygun olduğunu göstermektedir. 


\section{Araştırma Ölçekleri Normal Dağılım Analizi:}

Araştırmalarda, uygulanacak istatistiki yöntemler verilerin normal dağılım gösterip göstermediğine bağlı olarak değiştiğinden, istatistiki çalışmalara başlamadan önce verilerin normal dağııım analizi yapılmalıdır.

İstatistiksel analizlere geçilmeden, verilerin normal dağılım gösterip göstermediğine örneklem büyüklüğü 29'dan büyük olduğunda Kolmogorov-Simirnov testi, örneklem büyüklüğünün 29'dan küçük olması durumunda Shapiro Wilks Testi yapılarak bakılmaktadır (Kalaycı, 2009: 45-48).

Test sonucunda, elde edilen $p$ değeri $(p>0.05)$ dağılımın normal olduğunu, anlamlı olması halinde $(p<0.05)$ ise dağılımın normal dağılmadığını göstermektedir (Field, 2009: 48).

Değişken bazında verilerin dağılımı incelendiğinde 29'dan fazla sayıda veri elde etmiş olduğumuz için, Kolmogorov-Smirnov testi yapılarak Tablo 7.'deki Sig. değeri dikkate alınmaktadır. Örgütsel adaletin Sig. değerinin 0,2 olması normal dağıldığını, örgütsel bağlılık ve iş doyumu değişkenlerimizin Sig. değerlerinin 0,05'den küçük olması nedeniyle normal dağılmadıklarını göstermektedir.

Bu nedenle analizler de non-parametrik teknikler kullanılarak yapılmaktadır.

Tablo 4: Normal Dağılım Tablosu ( $\mathrm{N}=489$ )

\begin{tabular}{|l|l|l|l|}
\hline \multirow{2}{*}{} & \multicolumn{3}{l|}{ Kolmogorov-Smirnov ${ }^{\mathrm{a}}$} \\
\cline { 2 - 4 } & Statistic & $\mathrm{df}$ & Sig. \\
\hline İşlemsel Adalet & 035 & 489 &, $200^{*}$ \\
\hline Duygusal Bağlılık & 048 & 483 &, 010 \\
\hline İş Doyumu & 050 & 474 &, 006 \\
\hline
\end{tabular}

\subsection{ARAŞTIRMA BULGULARI}

Katılımcıların anket formunun ilk kısmında yer alan demografik özelliklerine ilişkin ifadelere verdikleri yanıtlar doğrultusunda frekans analizi yapılmıştır. Araştırmaya katılan hekimlerin cinsiyet, yaş aralığı, medeni durumu, unvanı, çalışılan kurum, toplam mesleki deneyim süresi ve değerlendirilen kurumdaki çalışma süresi ile ilgili bilgiler bu başlık altında yer almaktadır.

Katılımcıların cinsiyetleri incelendiğinde, 262 kişi ile \%53,6 oranla erkek, 227 kişi ile \%46,4 oranla kadın olduğu görülmektedir. Çalışmaya katılan hekimlerden her iki cinsiyet oranının birbirine yakın olduğu görülmektedir.

Veriler katılımcıların yaş aralığına göre incelendiğinde, 218 katılımcının \%44,6 oranla en fazla paya sahip olarak 41-55 yaş aralığında olduğu, ikinci olarak 163 katılımcı ile \%33,3 oranla 31-40 yaş aralığında, sonrasında 76 katılımcı ile \%15,5 oranla 21-30 yaş aralığında ve en az katılımcı sayısı da 32 kişi ile \%6,5 oranla 56 ve üzeri yaş aralığında görülmektedir.

Katılımcı hekimlerin medeni durumları açısından bakıldığında, 354 kişinin \%72,4 oranla evli, 135 kişinin de \%27,6 oranla bekar olduğu görülmektedir.

Katılımcılar unvanlarına göre incelendiğinde, katılımcılardan en fazla sahip olunan unvan 259 kişi ile \%53 oranla Pratisyen Doktor olarak görülmektedir. 180 katılımcının \%36,8 oranla Uzman Doktor, 21 katılımcının \%4,3 oranla Yrd. Doç. Dr., 15 katılımcının \%3,1 oranla Doç. Dr. ve 14 katılımcının \%2,9 oranla Prof. Dr. oldukları görülmektedir.

Katılımcıların çalışılan kuruma yönelik ifade analizinde, 250 katılımcının \%51,1 oranla kamu kurumunda, 198 katılımcının \%40,5 oranla özel kurumda ve 41 katılımcının \%8,4 oranla kendi işinde çalıştığı sonucuna ulaşılmaktadır.

Kendi işinde çalışan hekimler son çalıştıkları kurumu dikkate alarak formu yanıtladıkları için, bu katılımcıların en son çalıştıkları kurumun kamu ya da özel sektör olmasına yönelik bir ifade de formda yer almaktadır. Bu ifadeye verilen yanıtlar neticesinde, kendi muayenehanesinde çalışan 41 hekimden, 19 hekimin kendi işinden önce kamu kurumunda, 19 hekiminde özel kurumda çalıştığı ve kendi muayenehanesinde çalışan 41 kişiden 3 'ünün de son çalışılan kurumun kamu ya da özel kurum olmasına yönelik ifadeyi cevaplamadığı görülmektedir.

Demografik incelemelere yönelik katılımcıların deneyim sürelerine bakıldığında, 146 katılımcının \%29,9 oranla 21 yıl ve üzeri, 82 katılımcının $\% 16,8$ oranla 0-5 yıl aralığında, 82 katılımcının \%16,8 oranla 6-10 yıl aralığında, 94 katılımcının \%19,4 oranla 11-15 yıl aralığında, 85 katılımcının \%17,4 oranla 16-20 yıl aralığında mesleki deneyim sürelerine sahip oldukları sonuçlarına ulaşılmaktadır.

Formda ele aldığımız değişkenlere yönelik algıların ölçümüne ilişkin olarak, katılımcıların değerlendirmelerini istediğimiz son çalıştıkları kurumdaki deneyim sürelerine de bakıldığında, en fazla oranın \%50,3 olarak 246 katılımcının 0-5 yıl aralığında olduğu görülmektedir. 112 katılımcı \%22,9 oranla 6-10 yıl aralığında, 50 katılımcı \%10,2 oranla 11-15 yıl aralığında, 41 katılımcı \%8,4 oranla 16-20 yıl aralığında, 40 katılımcının \%8,2 oranla 21 yıl ve üzeri zaman aralığında çalıştığı sonuçlarına ulaşılmaktadır.

\section{Araştırma Değişkenleri Spearman Korelasyon Analizi}

Araştırmamızda elde ettiğimiz veriler normal dağılım göstermediği için değişkenlerin birbirleri arasında ilişkisinin yönüne ve gücüne Spearman Korelasyon analiz yöntemi ile bakılmıştır. 
Tablo 5: Spearman Korelasyon Analiz Tablosu

\begin{tabular}{|l|l|l|l|l|}
\hline $\mathrm{N}=489$ & & Örgütsel adalet & Örgütsel bağlılık & iş doyumu \\
\hline Örgütsel adalet & $\begin{array}{l}\text { Correlation } \\
\text { Coefficient } \\
\text { Sig. (2-tailed) }\end{array}$ & 1 & $0,482^{* *}$ & $0,604^{* *}$ \\
\hline Örgütsel bağllık & $\begin{array}{l}\text { Correlation } \\
\text { Coefficient } \\
\text { Sig. (2-tailed) }\end{array}$ & $0,482^{* *}$ & 0 & 0 \\
\hline İs doyumu & $\begin{array}{l}\text { Correlation } \\
\text { Coefficient } \\
\text { Sig. (2-tailed) }\end{array}$ & $0,604^{* *}$ & $0,421^{* *}$ & $0,421^{* *}$ \\
\hline
\end{tabular}

$\mathrm{H}_{2}, \mathrm{H}_{3}$, ve $\mathrm{H}_{4}$ hipotezlerimizin analizine yönelik, değişkenlerimiz arasında ilişki olup olmadığını belirleyebilmek için, spearman korelasyon analizi yapılmıştır. Örgütsel adaletin örgütsel bağlıı̆̆ı pozitif yönde 0,482 şiddetinde, örgütsel adaletin iş doyumunu pozitif yönde 0,604 şiddetinde ve örgütsel bağlılı̆ın iş doyumunu pozitif yönde 0,421 şiddetinde etkilediğini görmekteyiz. Non parametrik spearman korelasyon testi sonucunda üç hipotezimizin de doğruluğu ispatlanmıştır. Üç değişkenimiz arasında anlamlı bir ilişki olduğunun yanı sıra, en güçlü ilişkinin örgütsel adalet ve iş doyumu arasında olduğu görülmektedir.
$H_{2:}$ Örgütsel adalet algısı ile hekimin örgütsel bağııı̆ı̆ı arasında olumlu ilişki vardır.
$\mathrm{H}_{3}$ : Örgütsel adalet algısı ile hekimin iş doyumu arasında olumlu ilişki vardır.
$\mathrm{H}_{4}$ : Örgütsel bağlılık ile hekimin iş doyumunu arasında olumlu ilişki vardır.
$\mathrm{H}_{2}, \mathrm{H}_{3}$ ve $\mathrm{H}_{4}$ hipotezlerimiz bu bilgiler ışı̆̆ında kabul edilmiştir.

\section{Araştırma Değişkenleri Regresyon Analizi}

Sobel testi, sınırlı ya da tam aracılığın oluşmasında, yordayıcı değişkenin açıkladığı varyanstaki azalmanın anlamlılık düzeyini ölçen bir yöntem olarak tanımlanan bir testtir (Sobel, 1982: 290). Sobel test ile örgütsel adalet ile iş doyumu arasındaki ilişkide örgütsel bağ|lığın, örgütsel adaletin alt boyutları ile iş doyumu arasındaki ilişkide örgütsel bağılığın alt boyutlarının aracılık rolü incelenmiştir.

\section{Tablo 10: Regresyon -Sobel Test -Tablosu}

\begin{tabular}{|c|c|c|c|c|c|c|}
\hline $\begin{array}{l}\text { Bağımsız } \\
\text { Değişken }\end{array}$ & $\begin{array}{l}\text { Aracı } \\
\text { Değişken }\end{array}$ & $\begin{array}{l}\text { Bağımlı } \\
\text { Değişken }\end{array}$ & Sobel Test & Standart Sapma & $p$ & Değeri \\
\hline İşlemsel Adalet & $\begin{array}{l}\text { Duygusal } \\
\text { Bağ|ılık }\end{array}$ & İş Doyumu & 6.972 & 0.019 & 0 & \\
\hline
\end{tabular}

$\mathbf{H}_{1}$ (Ana Hipotez): Ișlemsel adalet algısı, duygusal bağlıık aracı değişkeni ile çalışanların (hekimlerin) iş doyumunu olumlu etkilemektedir.

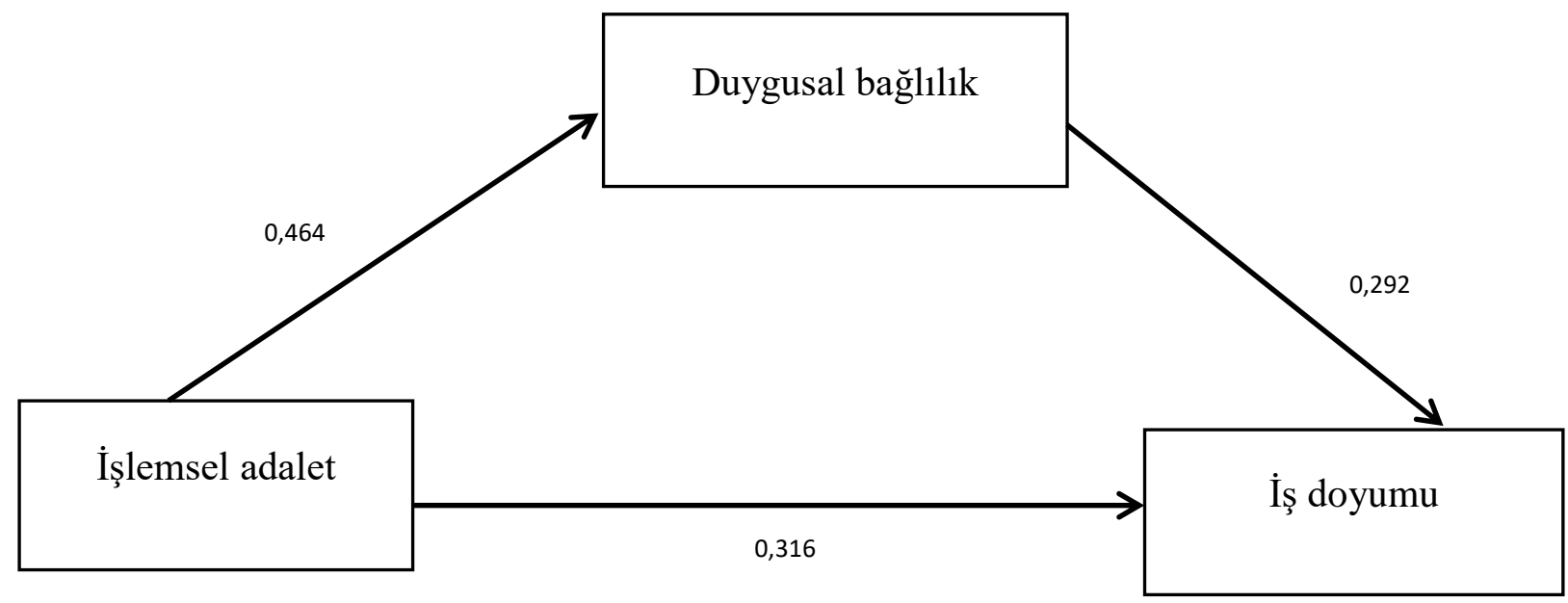


Sobel testi sonucunda işlemsel adaletin iş doyumu üzerindeki etkisinde duygusal bağılığın aracılık rolünün anlamlı olduğu sonucuna ulaşılmıştır (Sobel $t=6.972, p<0.05$ ). Buna göre, "İşlemsel adalet algısı, duygusal bağlılık aracı değişkeni ile çalışanların (hekimlerin) iş doyumunu olumlu etkilemektedir." $\left(\mathrm{H}_{1}\right)$ hipotezi kabul edilmiştir

\section{SONUÇLAR VE ÖNERILER}

Çalışmamızda hekimlerin örgütsel adalet, örgütsel bağlılık ve iş doyumu algılarının ölçülmesi ve demografik özelliklerinin üç değişkenimiz üzerindeki algılarında farklılık oluşturup oluşturmadığı, örgütsel bağlılık ve örgütsel bağıılığın alt boyutlarının örgütsel adalet ve örgütsel adaletin alt boyutlarının iş doyumu üzerindeki etkisinde aracılık etkisi olup olmadığı tespit edilmeye çalışılmış ve ilgili sonuçlara ulaşılmıştır.

$\mathrm{H}_{1}$ "İşlemsel adalet algısı, duygusal bağlılık aracı değişkeni ile çalışanların (hekimlerin) iş doyumunu olumlu etkilemektedir” hipotezi kabul edilmiştir. Yani duygusal bağlılık aracı değişkeni, işlemsel adaletin iş doyumu üzerine olumlu ve aracı bir etkiye sahiptir.

Örgütsel adalet ve örgütsel bağlılık, örgütsel adalet ve iş doyumu, örgütsel bağlılık ve iş doyumu arasındaki ilişkinin yönü ve şiddetine yönelik olarak Spearman Korelasyon analizi yapılmış ve aralarında pozitif yönde anlamlı ilişki olduğu sonucuna ulaşılmıştır. En güçlü ilişkinin de örgütsel adalet ve iş doyumu arasında olduğu belirlenmiştir. Elde edilen bu verilerle, "Örgütsel adalet algısı ile hekimin örgütsel bağlıı̆̆ arasında olumlu ilişki vardır." $\mathrm{H}_{2}$, "Örgütsel adalet ile hekimin iş doyumu arasında olumlu ilişki vardır." $\mathrm{H}_{3}$, ve "Örgütsel bağlılık ile hekimin iş doyumu arasında olumlu ilişki vardır." $\mathrm{H}_{4}$ hipotezlerimiz kabul edilmiştir.

Son yıllarda iş hayatında yaşanılan en önemli problemlerden birinin çalışanların memnuniyeti olduğu düşünüldüğünde, bu sorunun çözümüne yönelik çalışanların örgüte olan bağlılıklarını sağlanması önem arz etmektedir. Örgütler devamlılıklarını sağlamak istiyorlarsa, mutlaka çalışanların örgüte bağlılığının olması gerekmektedir. Örgütsel bağlılığa sahip olan çalışan, örgütün amaç ve hedeflerini benimser ve bunları kişisel amaçları haline getirir. Aynı zamanda örgüt üyeliğinin devamlılığı için güçlü bir istek duyar. Bu istek ve örgütle bütünleşme hali ile çalışanlara, yüksek verimlilik ve yüksek sorumluluk getireceği gibi, örgütün refahını mümkün kılan bir atmosferin varlığına da imkân sağlayacaktır.

Çalışanın örgüte olan bağlılığını sağlamak için de, örgüt yönetminin ödüllerin, çalışan haklarının, bilgilerin ve görevlerin dağtımında adil ve şeffaf olması gerekmektedir. Yönetimin, çalışanlarla arasındaki iletişimde oldukça önem arz etmektedir. Örgütün yapılacak işe uygun bilgiye ve yetkinliğe sahip bireyler ile çalışmaya önem vermeside önemlidir. Bu sayede işinde kendisini yeterli hisseden çalışanda, iş doyumu da söz konusu olacaktır.

Sağlık sektörünün temelini oluşturan hekimlerin hastalara yaptığı yanlış bir uygulama geriye dönüşü olmayacak sonuçlara neden olabilmektedir. Diğer sektörlerde geriye dönük işlemler çoğu kez yapılabilirken, sağlık sektöründe bunu sağlayabilmek mümkün değildir. Bu nedenlede, hekimler üzerindeki örgütsel bağlılık ve iş doyumu üzerinde durulması gereken ciddi konulardandır.

Örneklemimizi oluşturan hekimlerin büyük bir kısmının İstanbul'da yaşayan ve çalışan hekimler oluşturduğunu varsaymaktayız. Bu nedenle elde edilen sonuçlarda yaşanılan şehir şartlarınında etkili olabileceğini düşünerek, İstanbul dışında başka bir şehirde yaşayan ve çalışan hekimlerin bu konular üzerindeki algıları ölçülmeli ve bizim çalışmamızla karşılaştırılmalıdır.

Üzerinde çok fazla çalışılan konular olmasına rağmen aracılık etkisine yönelik çalışmalar az olduğundan, örgütsel adalet, örgütsel bağlılık ve iş doyumu konularının farklı meslek gruplarının algılarında bağlılığın aracılık etkisine yönelik çalışmalar yapılmalı ve hekimler üzerindeki çalışmamızın sonuçları ile karşılaştırılmalıdır.

\section{KAYNAKLAR}

Adams, J. S. (1965). Inequity in social exchange. Advances in experimental social psychology. Vol. 2. Academic Press, p. 267-299.

Allen, N. J., Meyer, J. P. (1990). The measurement and antecedents of affective, continuance and normative commitment to the organization. Journal of occupational and organizational psychology, vol 63, Academic Press 1, p.1-18.

Arslantürk, G., Şahan, S. (2012). Örgütsel adalet ve örgütsel bağlılık arasındaki ilişkinin manisa il emniyet müdürlüğü örnekleminde incelenmesi. Polis Bilimleri Dergisi, cilt 14, sayı 1, s.135-159.

Bayram, L. (2005). Yönetimde yeni bir paradigma: örgütsel bağlılık. Sayiştay Dergisi, Sayi 59, s.125-139.

Chang, E. (1999). Career commitment as a complex moderator of organizational commitment and turnover intention. Human Relations, Vol.52, Akademic Press 10, p.1257-1278.

Cihangiroğlu, N., Yılmaz, A. (2010). Çalışanların örgütsel adalet algısının örgütler için önemi. Sosyal Ekonomik Araştırmalar Dergisi, Cilt 10, baskı 19, s. 194-213.

Doğan, S., Kılıç, S. (2007). Örgütsel bağlılığın sağlanmasında personel güçlendirmenin yeri ve önemi. Erciyes Üniversitesi İktisadi Ve İdari Bilimler Fakültesi Dergisi, Sayı 29, s. 37-61.

Field, A. (2009). Discovering statistics using SPSS. Sage publications, 2009.

Greenberg, J. (1996). The quest for justice on the job: essays and experiments. Sage Publications, Incorporated, 1996.

Gül, H. (2002). Örgütsel bağlılık yaklaşımlarının mukayesesi ve değerlendirmesi. Ege Akademik Bakış Dergisi, Cilt 2 Sayı 1, s. 37-56. 
İşcan, Ö. F., Naktiyok, A. (2004). Çalışanların örgütsel bağdaşımlarının belirleyicileri olarak örgütsel bağlılık ve örgütsel adalet algıları. Ankara Üniversitesi Siyasal Bilgiler Fakültesi Dergisi, Cilt 59, Sayı 1, s.181-201.

Jeon, J. H. (2009). The impact of organizational justice and job security on organizational commitment exploring mediating effect of trust in top management. Doctoral Dissertation (Phd Thesis), University Of Minnesota.

Kalaycı, Ş. (2009). Spss uygulamalı çok değişkenli istatistik uygulamaları. Ankara, 2009.

Leventhal, G. S. (1980). What should be done with equity theory? Social exchange. Springer, Boston, MA, 1980, p. 27-55.

Meral, Y., Yaslıoğlu, M. (2017). Süreç adaletinin, iş doyumu ve banka birleşmesi sonrası yeni özdeşleşme üzerindeki etkileri ve yeni özdeşleşmenin bu ilişkideki aracı rolü. Global Busıness Research Congress 17, Cilt 2, Sayı 104, s.952-971.

Özdevecioğlu, M. (2003). Algılanan örgütsel adaletin bireylerarası saldırgan davranışlar üzerindeki etkilerinin belirlenmesine yönelik bir araştırma. Erciyes Üniversitesi İktisadi Ve İdari Bilimler Fakültesi Dergisi, Sayı 21, s.77-96.

Özmen, Ö. N., Arbak, Y., Süral Özer, P. (2007). Adalete verilen degerin adalet algilari uzerindeki etkisinin sorgulanmasina iliskin bir arastirma. Ege Akademik Bakış, Cilt 7, Sayı 1, s. 19-35.

Pekdemir, I., Özçelik, O., Karabulut, E., Arslantaş, C. C. (2006). Personel güçlendirme, iş tatmini ve örgütsel bağlılık arasındaki ilişkileri belirlemeye yönelik bir çalışma. Verimlilik Dergisi, Cilt 4, s. 11-36.

Pool, S. W. (1997). The relationship of job satisfaction with substitutes of leadership, leadership behavior, and work motivation. The Journal of Psychology, Vol. 131, Akademic Press 3, p.271-283.

Sipahi, B., Yurtkoru, E. S., Çinko, M. (2008). Sosyal bilimlerde Spss'le veri analizi. İstanbul, 2008.

Sobel, M. E. (1982). Asymptotic confidence intervals for indirect effects in structural equation models. Sociological Methodology, Vol. 13, p. 290-312.

Witt, L. A., Kacmar, M., Andrews, M. C. (2001). The interactive effects of procedural justice and exchange ideology on supervisor-rated commitment. Journal of Organizational Behavior, Vol. 22, Akademic Press 5, p. 505-515.

Yazıcıoğlu, İ., Topaloğlu, I. G. (2009). Örgütsel adalet ve bağlilik ilişkisi: konaklama işletmelerinde bir uygulama. İşletme Araştırmaları Dergisi, Cilt 1, Sayı 14, s.3-16.

Yeniçeri, Ö., Demirel, Y., Seçkin, Z. (2009). Örgütsel adalet ile duygusal tükenmişlik arasındaki ilişki: imalat sanayi çalışanları üzerine bir araştırma.

Yüceler, A. (2009). Örgütsel bağlılık ve örgüt iklimi ilişkisi: teorik ve uygulamalı bir çalışma'. Selçuk Üniversitesi Sosyal Bilimler Enstitüsü Dergisi, Sayı 22, s. 445-458. 